\title{
RISKS OF DIGITALISATION OF BUSINESS MODELS
}

\author{
Kristina KOVAITE் ${ }^{*}$, Jelena STANKEVIČIENE் (D) \\ The Faculty of Business Management, Vilnius Gediminas Technical University, \\ Sauletekio al. 11, LT-10223, Vilnius, Lithuania \\ *E-mail: kristina.kovaite@vgtu.lt
}

\begin{abstract}
Purpose - to identify the types of risks to be analysed during the process of digitalisation of business models driven by Industry 4.0 and determine which blocks of business model are affected most.

Research methodology - FARE method as a Multicriteria decision support method for expert evaluation is used.

Findings - results determine 6 types of risks: technical, competence, acceptance by staff, acceptance by customers and partners, data privacy and security and financial risks. The highest effect is shown in customer channels, key resources, and revenue stream and customer segmentation. The lowest effect is shown for key partners.

Research limitations - research focuses on the level of enterprise and does not cover macro-level risks.

Practical implications - Industry 4.0 brings new types of risks to be assessed. The results show that risk assessment matrix RADi (Risk Assessment of Digitalisation of Business Model) can be used by enterprises to identify areas of highest risks when planning and implementing digitalisation of parts or whole business model due to Industry 4.0.

Originality/Value - a new risk assessment matrix RADi (Risk Assessment of Digitalisation of Business Model) is developed by the authors as a contribution to the systematic approach to the changes occurring because of digitalisation in the business models.
\end{abstract}

Keywords: Industry 4.0, digitalisation, risk assessment, business model, multi-criteria methods, FARE method.

JEL Classification: D81, G32.

Conference topic: Contemporary Financial Management.

\section{Introduction}

Digitalisation due to Industry 4.0 is rapidly changing a way of behaviour of people and businesses. The 3rd industrial revolution introduced the use of the internet and approach of decentralisation of energy acquiring in 1970 and later. The 4th industrial revolution moves from there and encompasses a range of technological drivers as the Internet of things (IoT), big data, cloud computing, robotics, artificial intelligence and explores the decentralisation of communication between people and machines (Schwab, Davis, \& Nadella, 2018; Li, 2018; L. D. Xu, E. L. Xu, \& Li, 2018; Roblek, Meško, \& Krapež, 2016).

Research on the risk that technological drivers bring to businesses assessment can be found, but it is very seldom to find a systematised approach to risks and methods to test the changes in the business models if digitalised due to Industry 4.0. Most researchers agree that Industry 4.0 drivers make digitalisation fast and result unpredictable and bring additional to traditional risks to the changes of business models: the value of data, cybersecurity, the criticality of a function and scalability of failure, misuse of ownership, cost of a mistake, etc. Lack of previous theoretical researches and empirical evidence that one could rely on makes forecast of results during and after digitalisation complicated.

The article consists of four sections: the first section explores recent scientific publications referred in Clarative Analytics, most of them published not earlier than 2014 which brings to the theoretical model of risks that occur during the process of digitalisation of business models, the second section explains the empirical methodological part and methodological process of research, third section introduces to the results and findings of the research and fourth section comes up with the conclusions and invites for a discussion and further research. Researchers use analysis of the scientific literature and multicriteria decision support method (FARE method) are used. 
The article aims to determine the types of risks that appear under the impact of Industry 4.0 on business models and assess which types have more impact on different business model blocks.

\section{Literature review on risk assessment in business models driven by Industry 4.0}

The articles for this research were chosen out of those referred in the database of Clarivate Analytics. The articles were chosen using the keywords "risk", "Industry 4.0", "digitalisation", "business model". Some articles discuss approaches to the risk assessment of the overall business model (Haaker, Bouwman, Janssen, \& de Reuver, 2017) and others - on a specific parts of the business models (such as Supply chain, value capture, etc.) or separate pillars of Industry 4.0 (such as Internet of Things, Big data, etc.). Only 15 articles found where all dimensions are mentioned in the period between 2014 and 2018. A gap in researches focused on types of risks related to business models driven by Industry 4.0 is undoubtedly noticed.

The risk is commonly understood as a probability of a shift from the expected with a threat of damage, loss or any other usually negative consequence that may be avoided through preventive action. Risk often correlates with some uncertainty which always goes together with innovation and changes. Most researchers come to similar elements of the definition of risk.

Reim, Parida, and Sjödin (2016) works with the definition of risk "as a combination of the probability of loss and the impact of the loss for a number of events and risks" and describes it as a formula:

$$
R=P_{n} \cdot I_{n},
$$

where $R$ - risk, $P$ - the probability of loss of n events, $I$ - the impact of the loss of n events for the results of the enterprise, $n$ - the number of different events, risks, losses, or impacts.

Researchers on business models (Zott, Amit, \& Massa, 2011, 2010, 2013; Teece, 2017; Chesbrough, 2007, etc.), describe it as a business logic which includes a set of mechanisms, their more or less independent relationships between partners, customers and suppliers and explains the value creation and capturing of a company. It is a description of the value to customers, way to communicate and ,a simplified description and representation of what value is provided to customers, how this is done and with which financial consequences" in an enterprise (Osterwalder, Pigneur, \& Tucci, 2005).

Lots of researchers offer to change business models from a product based to service based, e.g. data and cloudbased models. As noticed during the literature review most of the researches use Osterwalder's Business model canvas as a basis for their researchers. Therefore the authors in this article use the business model canvas model by A. Osterwalder in 2004 and developed further on in 2010 and later as a basis for their research.

Most scientific attention is found on individual pillars of Industry 4.0 (such as Internet of things (Nurse, Creese, \& De Roure, 2017), big data (Niesen, Houy, Fettke, \& Loos, 2016), cloud computing, etc.) use of digitalisation and Industry 4.0 in different areas (such as smart home (Hui, Sherratt, \& Sánchez, 2017), (Jacobsson, Boldt, \& Carlsson, 2016), health, intelligent factories (Zhong, Xu, Klotz, \& Newman, 2017), etc.) or in the different patterns of business models, such as Supply chain (Revilla \& Saenz, 2017), value creation and capture (Orellano, Neubert, Gzara, \& LeDain, 2017), revenue stream.

With the fast transformations of economies, advantages and benefits of Industry 4.0 are widely discussed, says (Zheng, Ming, Li, \& He, 2015; Arnold, Kiel, \& Voigt, 2017; Burmeister, Lüttgens, \& Piller, 2016) while risks and uncertainties resulting from this transformation tide. Risks related to the making decision when choosing between alternatives to business models driven by Industry 4.0 are rarely investigated. Industry 4.0 drivers make shifts fast and result in unpredictable risks to the changes of business models: the value of data, cybersecurity, the criticality of a function and scalability of failure, misuse of ownership, cost of a mistake, etc.

Table 1 expands the understanding of the types of risks in the business models driven by Industry 4.0. The explanation is based on the literature review conducted by the authors of this article and brings to the matrix of risks of digitalisation of whole or parts of the business model.

There are a series of risks identified in different articles that can be clustered in 5 types: technical, competence, behavioural, data security and financial risks. Articles explain risks in different ways and show a variety of sources of risks. All the authors agree that internet technologies bring changes to market fast and the business model becomes too important to be left to random unplanned solutions.

Experts after evaluating five types of risks recommended splitting Behavioural risks into two depending on whether the source is inside or outside the organisation: risks related to staff skills and attitudes and risks related to customers' and partners' attitudes to changes.

After the analysis of literature and expert evaluation, a matrix of 6 types of risks RADi (Risk Assessment for Digitalisation) was created and introduced in this article. RADi is to be used when planning and implementing Industry 4.0 pillars into existing or new business models. 
Table 1. Findings of the risks of business models driven by Industry 4.0 (created by authors, 2019)

\begin{tabular}{|c|c|c|}
\hline Types of risks & Authors & Findings \\
\hline \multirow[t]{6}{*}{$\begin{array}{c}\text { Technical } \\
\text { risks }\end{array}$} & (Reim et al., 2016) & $\begin{array}{l}\text { Business must acquire numerous new capabilities and resources to be able to offer } \\
\text { product-service solutions (PSS) }\end{array}$ \\
\hline & (Nurse et al., 2017) & $\begin{array}{l}\text { Internet of things brings dynamism, and systems change fast. Technical } \\
\text { improvements make real-time risk identification and assessment realistic }\end{array}$ \\
\hline & (Orellano et al., 2017) & Data based solutions as a value creation and proposition \\
\hline & (Yigitbasioglu, 2015) & $\begin{array}{l}\text { Cloud computing delivery model makes technology outsourcing possible and shows } \\
\text { flexibility, the speed of deployment, and access to quality software. It is shown as a } \\
\text { cost-effective business model with a pay-per-use revenue stream }\end{array}$ \\
\hline & (Hassan, 2017) & IT resources have a significant influence on cloud computing adoption \\
\hline & $\begin{array}{l}\text { (Baecke \& Bocca, } \\
\text { 2017) }\end{array}$ & $\begin{array}{l}\text { Internet of Things enables companies to collect an increasing amount of sensor- } \\
\text { generated data }\end{array}$ \\
\hline \multirow[t]{3}{*}{$\begin{array}{c}\text { Competence } \\
\text { risks }\end{array}$} & $\begin{array}{l}\text { (Tupa, Simota, \& } \\
\text { Steiner, 2017) }\end{array}$ & The scarcity of human resource: new competence needed \\
\hline & (Yigitbasioglu, 2015) & $\begin{array}{l}\text { Regarding the perceived risks of cloud computing, there is evidence that } \\
\text { concerns... the lack of understanding to inhibit its adoption }\end{array}$ \\
\hline & (Nurse et al., 2017) & $\begin{array}{l}\text { The processes through which devices are interconnected and the information is } \\
\text { communicated without human; new devices are integrated very fast } \\
\text { Fast changes require more system thinking skills answering how to do rather than } \\
\text { knowing what to do; due to rapid changes and lack of knowledge important risks } \\
\text { might be missed }\end{array}$ \\
\hline \multirow[t]{2}{*}{$\begin{array}{c}\text { Behavioural } \\
\text { risks }\end{array}$} & (Reim et al., 2016) & $\begin{array}{l}\text { Behavioural risks include less careful behaviour when using a product that a } \\
\text { customer does not own (e.g. virtual solutions, extensive usage of the product or } \\
\text { service such as online reservation, anonymous comments, and possibilities for } \\
\text { unmanageable feedback in the social media) } \\
\text { Effects customer relationship, value proposition and cost structure as introduces } \\
\text { ownership vs access based business model and concept of "online everything" and } \\
\text { issues with ending up with the buying contract }\end{array}$ \\
\hline & $\begin{array}{l}\text { (Jacobsson et al., } \\
\text { 2016) }\end{array}$ & $\begin{array}{l}\text { The risks classified as high were either related to the human factor and the } \\
\text { competence or the software components of the system }\end{array}$ \\
\hline \multirow[t]{2}{*}{$\begin{array}{l}\text { Data security } \\
\text { risks }\end{array}$} & (Tupa et al., 2017) & $\begin{array}{l}\text { Majority of common risk factors in the manufacturing area are related to } \\
\text { information security, data loss, loss of integrity of information, errors of data } \\
\text { processing, a risk of cyber-attacks }\end{array}$ \\
\hline & (Nurse et al., 2017) & Cyber attacks, security of data and information \\
\hline \multirow[t]{3}{*}{$\begin{array}{c}\text { Financial } \\
\text { risks }\end{array}$} & (Zhou et al., 2017) & $\begin{array}{l}\text { As the investment nature is of a long cycle and high risk, the "organisational } \\
\text { factors" in the implementation are also non-ignorable }\end{array}$ \\
\hline & (Yigitbasioglu, 2015) & $\begin{array}{l}\text { Concerns the hidden costs of contracting and its performance } \\
\text { The impact on SMEs is higher as they potentially do not have access to large sums } \\
\text { of capital to invest in cutting-edge IT software and hardware }\end{array}$ \\
\hline & (Hassan, 2017) & IT investment has a major impact on cloud computing \\
\hline
\end{tabular}

\section{Research methods}

The research aims to find a matrix of risk assessment that would evaluate the effect of specific risks on blocks of business model canvas if digitalised due to Industry 4.0. After designing a matrix FARE method was used. Experts were asked to fill in a template for each type of risk, the average is calculated and the accumulated data is finally in the matrix of risk assessment. Figure 1 demonstrates the sequence of risk assessment to follow.

The conducted research design is described below.

1. Scientific literature analysis. The articles referred to in Clarivate Analytics during the period of 2014-2018 were chosen. 6 types of risks for 9 blocks of business model canvas were identified and a matrix of risk assessment RADi which consists of 6 step process was created.

2. Development of the template. When developing a template for expert evaluation a number $R$ of relationships $\mathrm{m}$ between the criteria should be kept within reasonable limits and can be calculated:

$$
R=\frac{m(m-1)}{2} .
$$

An increase of a number of relationships $m$ when increasing the number of criteria at least by one is observed, e.g. 9 criteria create 36 relationships for expert evaluation and 10 criteria create already 45 relationships. 
1. Identification of types of risks and criteria using scientific literature analysis

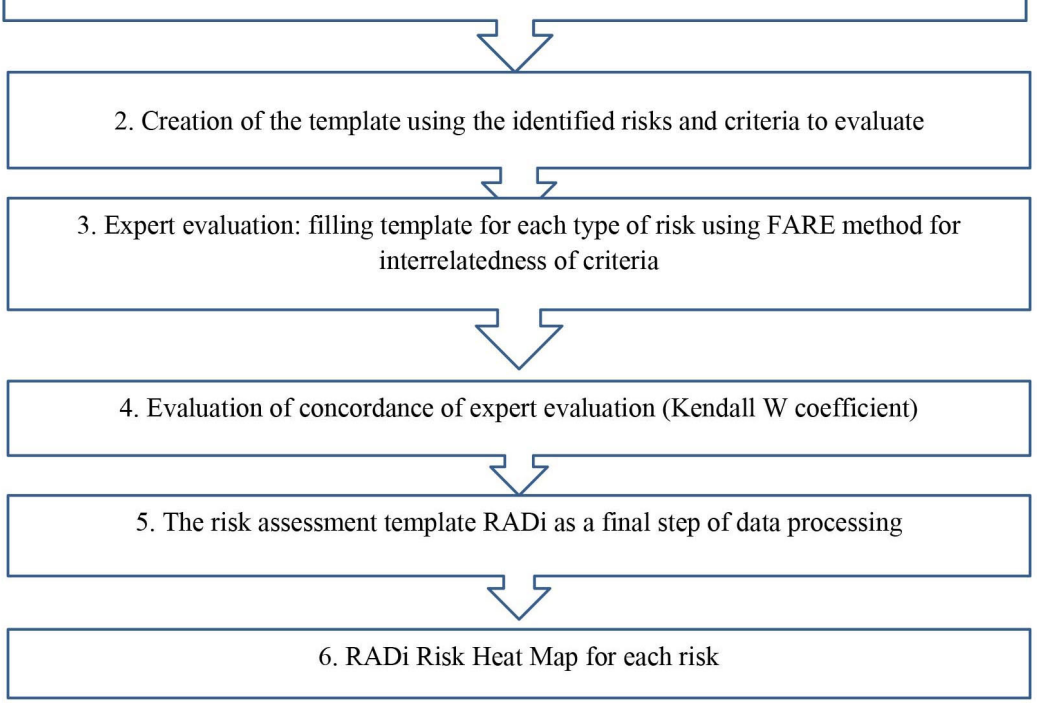

Figure 1. The 6 step Risk assessment for Digitalisation matrix RADi (created by authors, 2019)

3. Experts evaluation consists of two stages: selection of experts and expert evaluation filling in the templates.

Experts were selected according to the criteria: 1) each expert represent different economic area; 2) each of them has at least 10 years of managing experience in their specific industry; 3 ) each of them has competences related to Industry 4.0 issues. The number of experts is to be at least one more than a number of criteria. In the case of this article ten experts were selected.

FARE (Factor relationship) method is (Ginevičius, 2011) and others. The template for experts to fill in is presented in Table 5.

Experts are provided with the instructions and asked to answer the question: which block of business model canvas between two (indicated vertically compared with one horizontally) if digitalised is more affected by a specific risk. The scale of quantitative evaluation of interrelationship between the system's criteria is 0 to 5 when 0 means no difference between two criteria and 5 - very big difference between two criteria.

The normalisation of the values of the potential of the total impact of the criteria on the research object is calculated:

$$
w_{i}=\frac{P_{i}^{f}}{P_{S}}=\frac{P_{1}-m a_{1 i}+S(m-1)}{m S(m-1)} .
$$

The total potential required for determining the criteria weights calculated based on the data collected by expert evaluation from a summary matrix of the potential equilibrium of the criteria:

$$
P_{i}=P_{1}-m^{*} a_{1 i},
$$

where $P_{i}$ is the total impact of the ith criterion.

The sum of the total impact values ( $\left.P_{i}\right)$ of the individual system's criteria on the research object is equal to zero:

$$
\sum_{i=1}^{m} P_{i}=\sum_{i=1}^{m}\left(P_{1}-m a_{1 i}\right)=m P_{1}-m \sum_{i=1}^{m} a_{i}=m P_{i}-m P_{1}=0
$$

where: $P_{i}$ is the total impact, $\mathrm{m}$ is the number of relationships, $a_{1 i}$ is the value of the matrix element of the ith row of the jth column; $a_{1 j}$ and $a_{1 i}$ are the first row elements.

When creating the template the same criteria should be horizontally and vertically.

$$
w_{i}=\frac{P_{i}^{f}}{P_{S}}=\frac{P_{1}-m a_{1 i}+S(m-1)}{m S(m-1)} .
$$

4. Kendall's coefficient (Podvezko, 2004) is used to measure the agreement among assessments of experts. 
The values of the coefficient are between 0 and 1. Kendall's W coefficient of concordance value being close to 1 shows that experts' assessments are unanimous and value being close to 0 shows that experts' assessments vary very much.

The concordance calculation according to Kendall's W coefficient is calculated by each ranked object.

Kendall's coefficient is calculated by the following formula:

$$
W=\frac{12 S}{r^{2} n\left(n^{2}-1\right)-r \sum_{j=1}^{r} T_{j}},
$$

where: $r$ - the number of experts, $n$ - the number of objects to evaluate.

$$
S=\sum_{i=1}^{m}\left(e_{i}-\bar{e}\right),
$$

where $S$ - a sum-of-squares statistic over the row sums of ranks $m_{i}, e_{i}$ - a sum of ranks, $\bar{e}-$ an average of sums of ranks.

$$
T_{j}=\sum_{k=1}^{H j}\left(t_{k}^{3}-t_{k}\right)
$$

where $T-$ an indicator of tied ranks of $\mathrm{j}$ expert, $H$ - the number of ranks of the same value of the $j$ expert, $t_{k}-$ number of equal tied ranks in each $(k)$ group of ties

$$
\text { ChiSq }=\operatorname{Wr}(m-1) \text {. }
$$

5. Data received after evaluation of relationships between criteria using FARE method is assessed in the risk assessment matrix RADi and presented in the tables below.

\section{Research results}

After analysing the scientific literature, the matrix of 6 types of risks: technical, competence, acceptance by staff, acceptance by clients, data security and financial risks, was developed.

Table 2. The relationship between the main criterion and other criteria and weights (developed by authors, 2019)

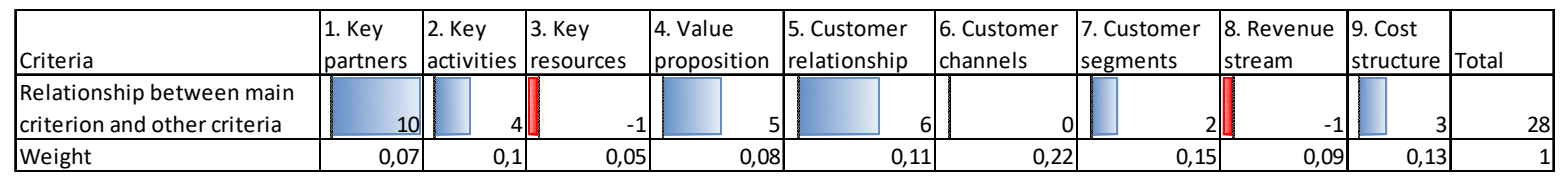

In Table 2 customer channels are identified as the main criterion after the expert evaluation. In a row "Relationship between main criterion and other criteria" blue means positive relation means, i.e. a specific criterion is seen as less affected by risks than main criterion Red means negative relation, i.e. a specific criterion is seen as more affected by risks than the main criterion.

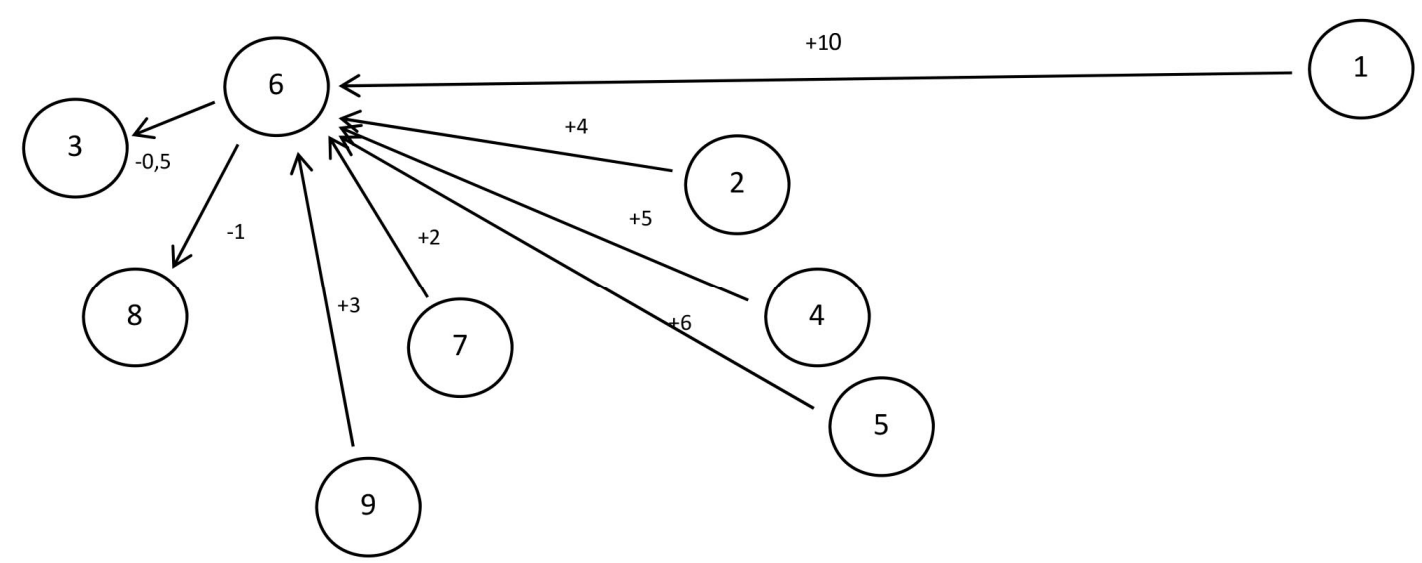

Figure 2. The relationship between the main criterion and other criteria (developed by authors, 2019) 
Figure 2 demonstrates the relationship between the main criterion (in a current situation - customer channel) and other criteria. The direction of the arrow in Figure 2 shows the direction of the relationship between the criteria. This means that the arrow goes from stronger criteria, i.e. a criterion which has less effect by risks. The results are presented in Table 3 and Table 4.

Table 3. The results of the risk matrix of RADi (developed by authors, 2019)

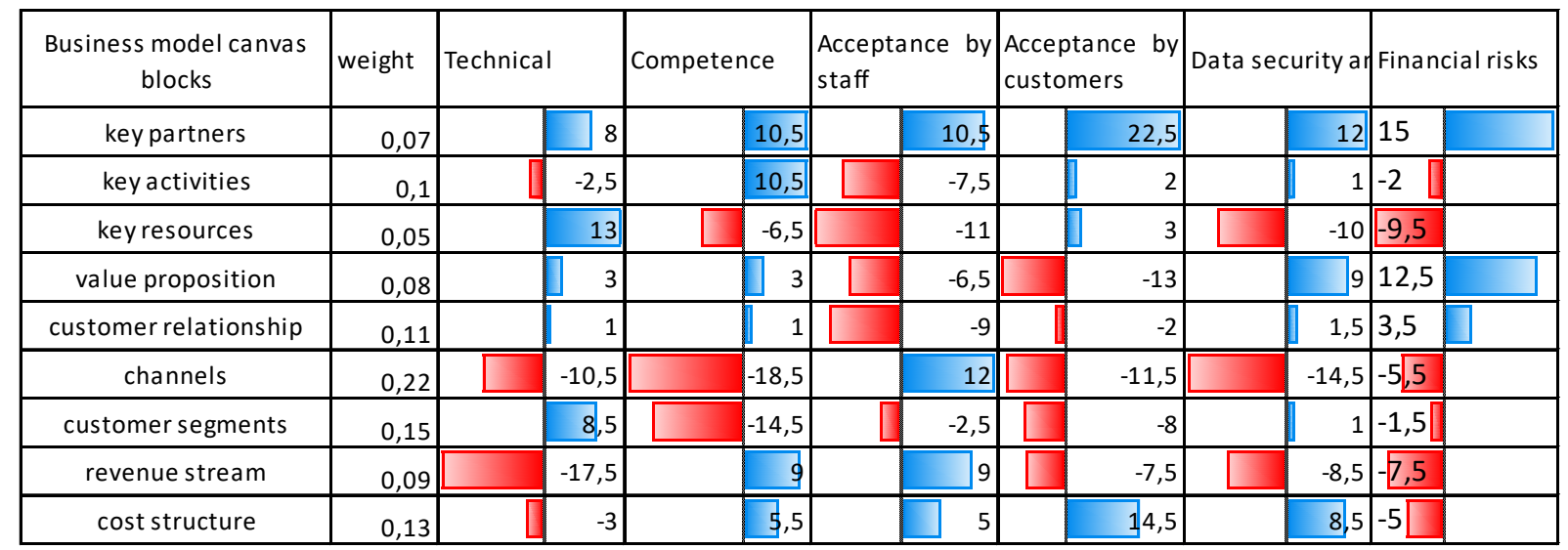

Table 4. The total effect (dependence) of the criteria describing the research object (developed by authors, 2019)

\begin{tabular}{|c|c|c|c|c|c|c|c|c|c|c|c|c|}
\hline $\begin{array}{c}\text { Business } \\
\text { Model } \\
\text { Blocks }\end{array}$ & $\begin{array}{l}\text { key } \\
\text { part } \\
\text { ners }\end{array}$ & $\begin{array}{c}\text { key } \\
\text { activit } \\
\text { ies }\end{array}$ & $\begin{array}{l}\text { key } \\
\text { resourc } \\
\text { es }\end{array}$ & $\begin{array}{l}\text { value } \\
\text { proposit } \\
\text { ion }\end{array}$ & $\begin{array}{l}\text { custo } \\
\text { mer } \\
\text { relatio } \\
\text { nship }\end{array}$ & $\begin{array}{l}\text { custo } \\
\text { mer } \\
\text { chann } \\
\text { els } \\
\end{array}$ & $\begin{array}{l}\text { custo } \\
\text { mer } \\
\text { segme } \\
\text { nts }\end{array}$ & $\begin{array}{c}\text { reven } \\
\text { ue } \\
\text { strea } \\
\text { m } \\
\end{array}$ & $\begin{array}{l}\text { cost } \\
\text { struct } \\
\text { ure }\end{array}$ & $\begin{array}{c}\text { total } \\
\text { effect } \\
\text { (depende } \\
\text { nce); } P_{i}\end{array}$ & $P_{i}^{f}$ & $\begin{array}{l}\text { wei } \\
\text { ght }\end{array}$ \\
\hline key partners & 0 & -11.5 & -9 & -6.5 & -13 & -16 & -7.5 & -7 & -8 & -78.5 & -27 & 0.07 \\
\hline $\begin{array}{c}\text { key } \\
\text { activities }\end{array}$ & 11.5 & 0 & -0.5 & 2 & -5 & -7 & -2 & -2 & 1.5 & -1.5 & 50.5 & 0.1 \\
\hline $\begin{array}{c}\text { key } \\
\text { resources }\end{array}$ & 9 & 0.5 & 0 & -2.5 & 2 & 0.5 & 1 & 2.5 & 8 & 21 & 73 & 0.05 \\
\hline $\begin{array}{c}\text { value } \\
\text { proposition }\end{array}$ & 6.5 & -2 & 2.5 & 0 & -2 & -9 & -2 & -4 & 2 & -8 & 44 & 0.08 \\
\hline $\begin{array}{l}\text { customer } \\
\text { relationship }\end{array}$ & 13 & 5 & -2 & 2 & 0 & -9.5 & -7 & -1 & 3.5 & 4 & 56 & 0.11 \\
\hline $\begin{array}{l}\text { customer } \\
\text { channels }\end{array}$ & 16 & 7 & -0.5 & 9 & 9.5 & 0 & 4 & -1 & 4.5 & 48.5 & 101 & 0.22 \\
\hline $\begin{array}{l}\text { customer } \\
\text { segments }\end{array}$ & 7,5 & 2 & -1 & 2 & 7 & -4 & 0 & -3 & 6.5 & 17 & 69 & 0.15 \\
\hline $\begin{array}{c}\text { revenue } \\
\text { stream }\end{array}$ & 7 & 2 & -2.5 & 4 & 1 & 1 & 3 & 0 & 7.5 & 23 & 75 & 0.09 \\
\hline $\begin{array}{c}\text { cost } \\
\text { structure }\end{array}$ & 8 & -1.5 & -8 & -2 & -3.5 & -4.5 & -6.5 & -7.5 & 0 & -25.5 & 26.5 & 0.13 \\
\hline & & & & & & & & & & 0 & 468 & 1 \\
\hline
\end{tabular}

The results in Table 3 show the impact of a concrete risk (horizontally) on each block of the business model canvas (vertically). Red shows a higher risk on a block of business model canvas and blue shows lower risk on a block.

Key partners are of the lowest risk in each of the risk categories and overall risk as all the evaluations are positive. Experts' given weight is (0.07) is the least and indicates that block key partners are of the lowest risk if digitalised.

Customer channels are of the highest risk in all of the risk categories except acceptance by staff risk. Having also the highest expert given weight (0.22) this block becomes of the highest risk if digitalised. Next high risk in customer channels is shown in areas of competence, data security and acceptance by staff. A positive number is the risk category Acceptance by staff indicate a low risk to customer channels.

The second weight is given to customer segments $(0.15)$ by experts. The highest risks can be seen in competence, acceptance by customers, the lowest - technical, and acceptance by staff, data security and financial risks are seen as comparatively neutral. 
The rest risk categories have different levels of effect on the rest blocks of the business model canvas. Results can be interpreted using the same logic as above.

Table 4 shows the results of research using FARE method according to the method of (Ginevičius, 2011). Results show dependencies between blocks of business models in regard to all 6 risk categories. The positive number shows the lower dependency of the horizontally indicated block in comparison to the vertical block. The negative number shows the higher dependency of the horizontally indicated block in comparison to the vertical block.

Following blocks of the business model canvas are seen as potentially most affected by all the categories of risks (in the sequence from highest): customer channels, key resources, and revenue stream and customer relationship. Blocks such as key partners, value proposition and cost structure seen as potentially least affected by digitalisation of business models.

Literature research showed the gap in the scientific literature: risk assessment of digitalisation of business models driven by Industry 4.0 is not researched enough though it is an important step towards a ground decision for changes and investment. After processing and analysing data of the research several aspects to discuss are raised.

Using FARE method experts compare the interrelatedness between factors and this gives additional insights to the direct research question. Therefore the selection of criteria is a critically important step. Having a bigger number of criteria would bring complications in the process of collecting data and in the interpretation of it.

\section{Conclusions}

The article contributes to the scientific literature with the development of a matrix of risk assessment $\mathrm{n}$ business models driven by Industry 4.0. A matrix of risk assessment RADi is introduced and tested. RADi uses FARE method which allows evaluating the relation between two factors against an object.

The article contributes to the practical level introducing a model of risk assessment RADi to enterprises as a decision making support tool. Enterprises can use RADi model when planning and implementing the changes in the business model or designing new business models driven by Industry 4.0. RADi indicates types of risks that have more effect on concrete blocks of the business model and assess which blocks can be more affected by changes.

The article contributes to the national level and can be used as a part of policy decision making methodologies. The policymakers can use RADi model to identify more risky areas of business model digitalisation, e.g. if support to digitalisation of businesses, improvements in regional development or SME development is planned.

Types of risks can differ in different stages of business model innovation. Further research would bring a wider perspective of the risks and their effect that business should take into account when planning and implementing digitalisation and innovation of the business model.

Research introduced in the article has some limitations. RADi matrix covers risks from micro and mezzo levels. Uncovered macro-level risks can be integrated into the expert evaluation for further researches. The interpretation of data should consider the fact of data integration.

Future research might cover the integration of data from the macro level in the risk assessment matrix as mentioned above and also a new concept of Industry 5.0 arising which focuses on social implications of technological and business model disruption.

\section{Disclosure statement}

The authors do not have any competing financial, professional, or personal interests from other parties.

\section{References}

Arnold, C., Kiel, D., \& Voigt, K. I. (2017). Innovative business models for the industrial internet of things. BHM Berg-und Hüttenmännische Monatshefte, 162(9), 371-381. https://doi.org/10.1007/s00501-017-0667-7

Burmeister, C., Lüttgens, D., \& Piller, F. T. (2016). Business model innovation for Industrie 4.0: Why the "Industrial Internet" mandates a new perspective on innovation. Die Unternehmung, 70(2), 124-152.

Baecke, P., \& Bocca, L. (2017). The value of vehicle telematics data in insurance risk selection processes. Decision Support Systems, 98, 69-79. https://doi.org/10.1016/j.dss.2017.04.009

Chesbrough, H. (2007). Business model innovation: It's not just about technology anymore. Strategy and Leadership, 35(6), 1217. https://doi.org/10.1108/10878570710833714

Ginevičius, R. (2011). A New determining method for the criteria weights in multicriteria evaluation. International Journal of Information Technology \& Decision Making, 10(06), 1067-1095. https://doi.org/10.1142/S0219622011004713

Haaker, T., Bouwman, H., Janssen, W., \& de Reuver, M. (2017). Business model stress testing: A practical approach to test the robustness of a business model. Futures, 89, 14-25. https://doi.org/10.1016/j.futures.2017.04.003

Hassan, H. (2017). Organisational factors affecting cloud computing adoption in small and medium enterprises (SMEs) in service sector. Procedia Computer Science, 121, 976-981. https://doi.org/10.1016/j.procs.2017.11.126 
Hui, T. K. L., Sherratt, R. S., \& Sánchez, D. D. (2017). Major requirements for building Smart Homes in Smart Cities based on Internet of Things technologies. Future Generation Computer Systems, 76, 358-369. https://doi.org/10.1016/j.future.2016.10.026

Jacobsson, A., Boldt, M., \& Carlsson, B. (2016). A risk analysis of a smart home automation system. Future Generation Computer Systems, 56, 719-733. https://doi.org/10.1016/j.future.2015.09.003

Li, L. (2018). China's manufacturing locus in 2025: With a comparison of "Made-in-China 2025" and "Industry 4.0". Technological Forecasting and Social Change, 135, 66-74. https://doi.org/10.1016/j.techfore.2017.05.028

Niesen, T., Houy, C., Fettke, P., \& Loos, P. (2016). Towards an integrative big data analysis framework for data-driven risk management in industry 4.0. In 2016 49th Hawaii International Conference on System Sciences, Koloa, HI, USA, 10 March (pp. 5065-5074). IEEE. https://doi.org/10.1109/HICSS.2016.627

Nurse, J. R. C., Creese, S., \& De Roure, D. (2017). Security risk assessment in internet of things systems (pp. 1-9). Retrieved from https://www.cs.ox.ac.uk/files/9680/2017-itpro-ncd_author-final.pdf

Orellano, M., Neubert, G., Gzara, L., \& Le-Dain, M. A. (2017). Business model configuration for PSS: An explorative study. Procedia CIRP, 64, 97-102. https://doi.org/10.1016/j.procir.2017.03.008

Osterwalder, A., Pigneur, Y., \& Tucci, C. L. C. (2005). Clarifying business models: origins, present, and future of the concept. Communications of the Association for Information Systems, 16(1), 1-25. https://doi.org/10.17705/1CAIS.01601

Podvezko, V. (2004). Ekspertų įverčių suderinamumas. Technological and Economic Development of Economy, 2, 101-107.

Reim, W., Parida, V., \& Sjödin, D. R. (2016). Risk management for product-service system operation. International Journal of Operations \& Production Management, 36(6), 665-686. https://doi.org/10.1108/IJOPM-10-2014-0498

Revilla, E., \& Saenz, M. J. (2017). The impact of risk management on the frequency of supply chain disruptions. International Journal of Operations \& Production Management, 37(5), 557-576. https://doi.org/10.1108/IJOPM-03-2016-0129

Roblek, V., Meško, M., \& Krapež, A. (2016). A complex view of Industry 4.0. SAGE Open, 6(2), 1-11. https://doi.org/10.1177/2158244016653987

Schwab, K., Davis, N., \& Nadella, S. (2018). Shaping the fourth industrial revolution. Currency.

Teece, D. J. (2017). Business models and dynamic capabilities. Long Range Planning, 51(1), 40-49. https://doi.org/10.1016/j.lrp.2017.06.007

Tupa, J., Simota, J., \& Steiner, F. (2017). Aspects of risk management implementation for Industry 4.0. Procedia Manufacturing, 11, 1223-1230. https://doi.org/10.1016/j.promfg.2017.07.248

Xu, L. D., Xu, E. L., \& Li, L. (2018). Industry 4.0: state of the art and future trends. International Journal of Production Research, 7543, 1-22. https://doi.org/10.1080/00207543.2018.1444806

Yigitbasioglu, O. M. (2015). The role of institutional pressures and top management support in the intention to adopt cloud computing solutions. Journal of Enterprise Information Management, 28(4), 579-594. https://doi.org/10.1108/JEIM-09-2014-0087

Zheng, M., Ming, X., Li, M., \& He, L. (2015). A framework for Industrial Product-Service Systems risk management. Proceedings of the Institution of Mechanical Engineers, Part O: Journal of Risk and Reliability, 229(6), 501-516. https://doi.org/10.1177/1748006X15588006

Zhong, R. Y., Xu, X., Klotz, E., \& Newman, S. T. (2017). Intelligent manufacturing in the context of Industry 4.0: a review. Engineering, 3(5), 616-630. https://doi.org/10.1016/J.ENG.2017.05.015

Zhou, Z., Liu, X., Pei, J., Pardalos, P. M., Liu, L., \& Fu, C. (2017). Real options approach to explore the effect of organizational change on IoT development project. Optimization Letters, 11(5), 995-1011. https://doi.org/10.1007/s11590-016-1006-8

Zott, C., Amit, R., \& Massa, L. (2011). The business model: Recent developments and future research. Journal of Management, 37(4), 1019-1042. https://doi.org/10.1177/0149206311406265 